\title{
A NEW ISOPOD CRUSTACEAN FROM PACIFIC PANAMA, EXCIROLANA CHAMENSIS NEW SPECIES (ISOPODA: FLABELLIFERA: CIROLANIDAE)
}

\author{
Richard C. Brusca ${ }^{1}$ and James R. Weinberg ${ }^{2}$
}

\begin{abstract}
A new species of cirolanid isopod is described, Excirolana chamensis new species, with remarks on its distribution and ecology. Excirolana chamensis is currently known only from the littoral zone of Pacific Panama. This brings the number of nominate Excirolana species in the eastern Pacific to 10. Excirolana chamensis is sympatric with the widespread E. braziliensis, and several additional undescribed species in this genus. Excirolana chamensis is a small species (length $2.4-4.3 \mathrm{~mm}$ ), that can be quickly distinguished from the similar E. braziliensis by its 2 -articulate mandibular palp and large stellate chromatophores, as well as other characters.
\end{abstract}

\section{INTRODUCTION}

The genus Excirolana Richardson, 1912, contains 17 recognized species, nine of which have been reported from the east Pacific: E. chiltoni (Richardson, 1905) and E. linguifrons (Richardson, 1905) from the temperate northeast Pacific; $E$. chilensis Richardson, 1912, E. hirsuticauda Menzies, 1962, and E. monodi Carvacho, 1977, from Chile; E. braziliensis Richardson, 1912, and E. mayana (Ives, 1891) from the tropical west Atlantic and tropical east Pacific; and E. koepckei (Bott, 1954) and E. salvadorensis (Schuster, 1954), endemic to the tropical east Pacific. Since the turn of the century, the status of many of these species has been confused, and numerous synonyms and homonyms exist in the literature. The status of E. koepckei and E. salvadorensis, which were synonymized with $E$. braziliensis by Glynn et al. (1975), is currently being reinvestigated, and several additional undescribed Excirolana species are known to exist in the east Pacific. The east Pacific Excirolana are currently being monographed by R. Brusca, thus the above species will not be discussed in the present paper. We are concerned here only with $E$. chamensis new species, a species very similar in appearance to, and sympatric in the east Pacific with, $E$. braziliensis. A fair amount of ecological research has already been accomplished based on the assumption that there is only one species of Excirolana (E. braziliensis) occurring on tropical east Pacific sand beaches (Dexter, 1972, 1974, 1976, 1977, 1979; Glynn et al., 1975). All comparisons to E. bra- ziliensis noted below are based on examination of the holotype of E. braziliensis (USNM Cat. No. 43655, off Cape St. Roque, Brazil) as well as additional collections of this species from the Caribbean and east Pacific. The following abbreviations are used in this paper: PMS, plumose marginal setae; LACM, Los Angeles County Museum of Natural History; USNM, U.S. National Museum of Natural History, Smithsonian Institution.

\section{SYSTEMATICS \\ Order Isopoda \\ Suborder Flabellifera \\ Family Cirolanidae \\ Excirolana chamensis new species}

Material Examined. Holotype (LACM type No. 3013): Panama, near Panama City, polluted beach near old part of town by National Theater; 15 Dec. 1984; coll.: J. Weinberg; male, length $4.3 \mathrm{~mm}$. Paratype (LACM type No. 3014): same locality and collection as holotype; 1 male, head broken from body. Paratypes (LACM type No. 3015): Panama, near Panama City, Pt. Chame Bay; fine sand beach; 25 Sept. 1984; coll.: J. Weinberg; 5 adults (lengths $2.4-2.6 \mathrm{~mm}$ ), 3 mancas (length $1.7 \mathrm{~mm}$ each). USNM Acc. No. 365596: Panama, near Panama City, Pt. Chame Bay; upper intertidal, fine sand beach; coll.: J. Weinberg; 5 adults (lengths 3.1-3.6 mm), 2 mancas (lengths $1.6-2.3 \mathrm{~mm}$ ).

Type Locality. Pacific Panama, near Panama City, Pt. Chame Bay.

1. Invertebrate Zoology Section, Natural History Museum of Los Angeles County, 900 Exposition Boulevard, Los Angeles, California 90007.

2. Woods Hole Oceanographic Institution, Woods Hole, Massachusetts 02543 . 

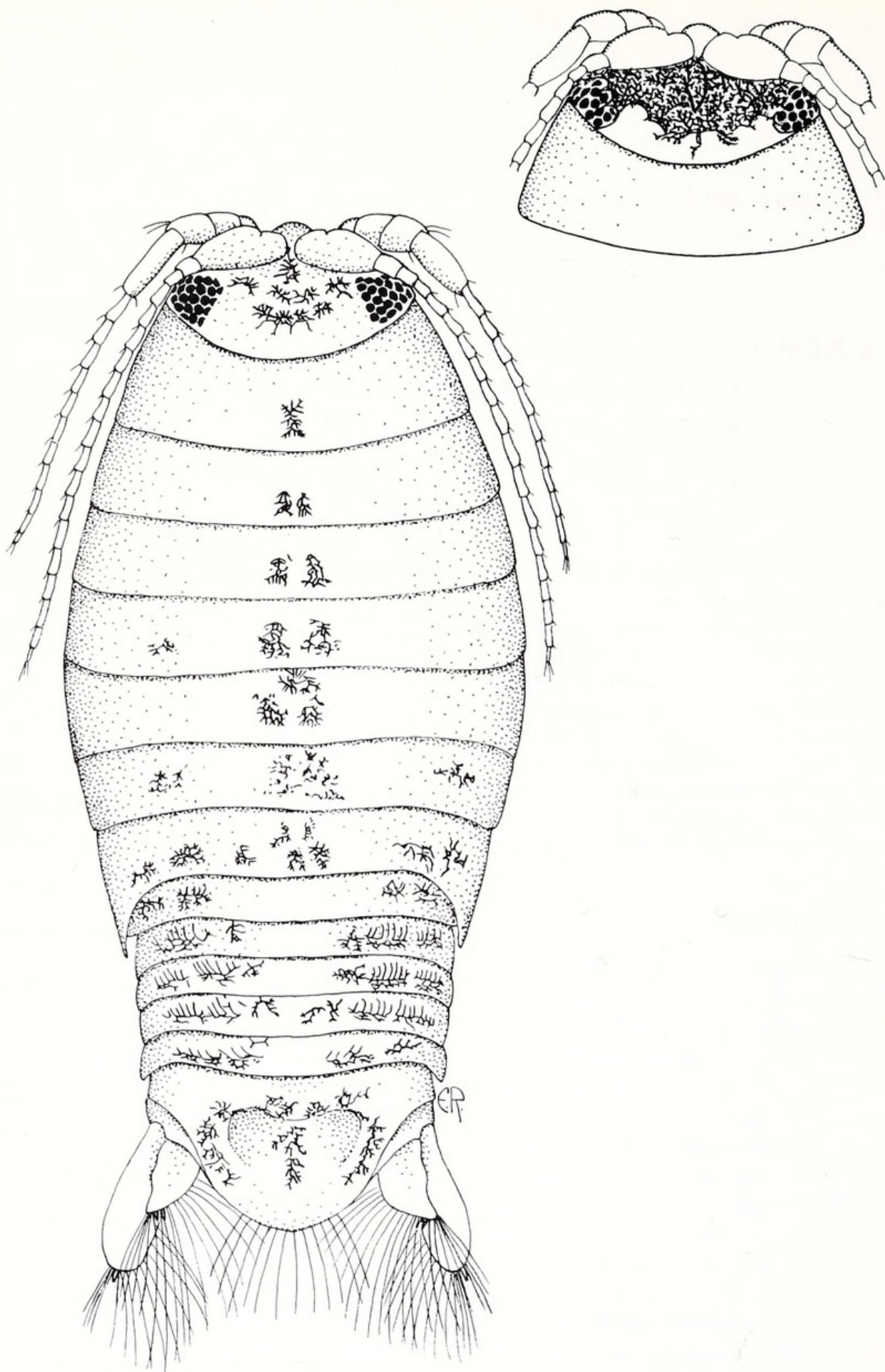

Figure 1. Excirolana chamensis new species. Holotype (LACM type No. 3013). Inset: head of paratype (LACM type No. 3015).

Diagnosis. Dorsal surface ornately pigmented with stellate chromatophores, occurring in band between eyes on cephalon, in median row on pereon, and in lateral rows on pleon. Eyes small, interocular distance greater than width of one eye. Antennules longer than antennae; antennule peduncle 2 -articulate because articles 1 and 2 are fused; article 3 small, not much larger than first flagellar article. Antenna peduncle 4-articulate, articles 1-3 subequal, article 4 longest. Mandible with 2-articulate palp. Maxilliped with single coupling hook. Pereopods with acute spines along inner margin and acute dactyls (never with blunt or truncated spines or dactyls); pereopod I ischium with several stout spines. Pereopod VII ischium without lateral spines. Pleonite 1 not hidden by pereonite VII. Pleopod 5 endopod fully divided. Pleotelson posterior border round, without marginal spines. Uropod exopod nearly twice as long as endopod, with 6 long, thin, simple, 


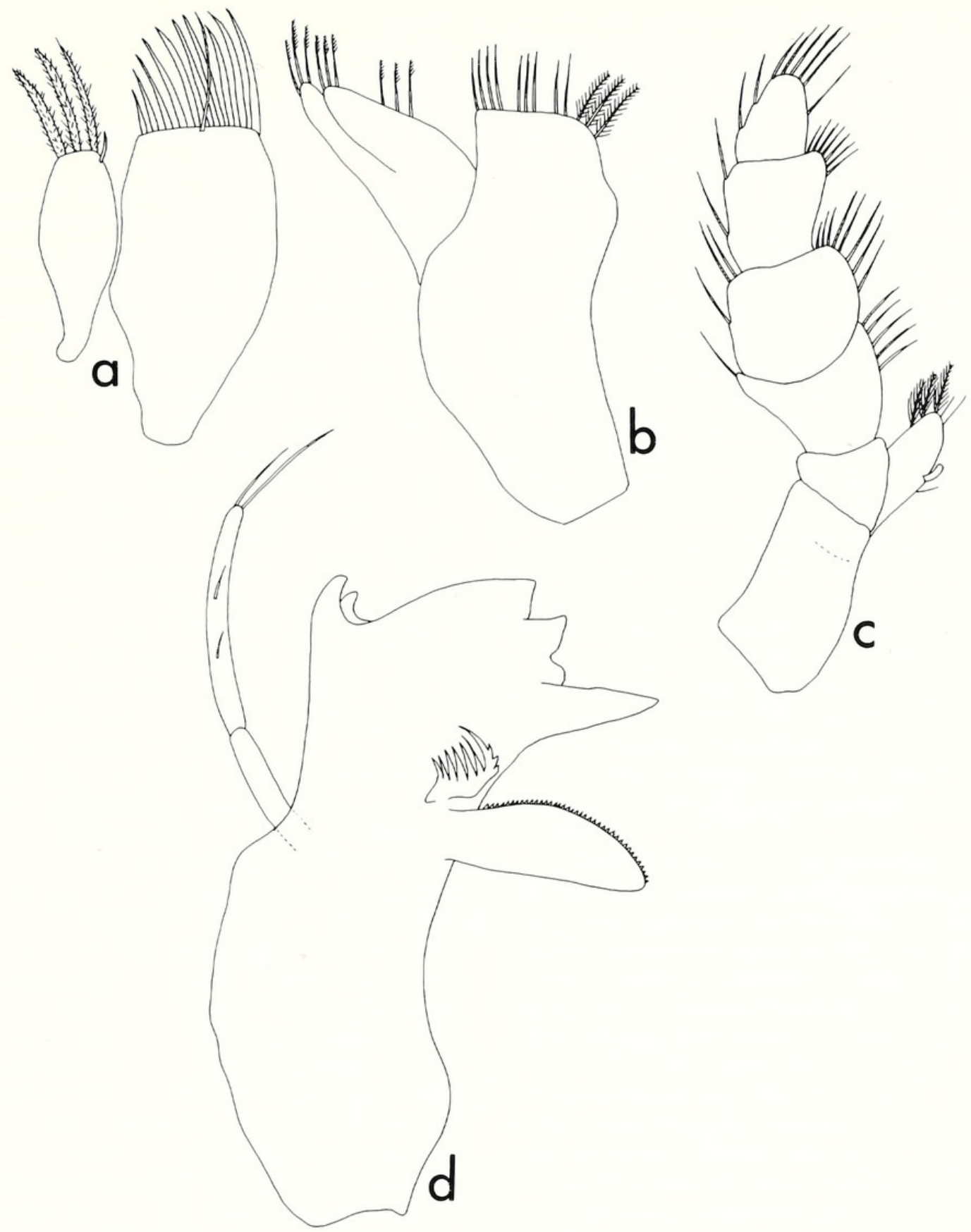

Figure 2. A, right maxillule. B, right maxilla. C, right maxilliped. D, left mandible (from male paratype, LACM type No. 3014).

apical spines, 2 large medial spines, and numerous very short medial spines or denticles; with plumose setae on medial margin and apex. Uropod endopod extended barely to posterior margin of pleotelson; with 3 distomedial spines, and plumose setae along distal inner and outer margins. Flat surfaces of both uropodal rami covered with very fine setae. Appendices masculinae of males arise off proximal lamellar lobe of endopod, $1 / 3$ distance up base; stout and short, not reaching apex of endopod. Adults $2.4-4.3 \mathrm{~mm}$ long (front of cephalon to posteriormost tip of pleotelson).

Description. Body smooth and evenly convex. Cephalon with a band of medial chromatophores between eyes, usually discernable as 3 distinct, separate bands; 2 states of cephalic chromatophore pigment dispersion occur in the type series, state 1 being a less dispersed state (Figure 1), and state 2 being a more dispersed state appearing to the naked eye almost as a black band across the head (Figure 1, inset). J. Weinberg has seen intermediate forms between these two extremes. Eyes small, width much less than interocular distance.

Antennules long, extending to pereonite $\mathrm{V}$; peduncle 2-articulate, because articles 1 and 2 are fused; article 3 not much larger than first article of flagellum; flagellum of 7-12 (6 in mancas) articles. Antennae shorter, extending to pereonite IV; peduncle 4-articulate, articles 1, 2, and 3 subequal, 4 longest; articles 2 and 3 with small denticles or spinules 

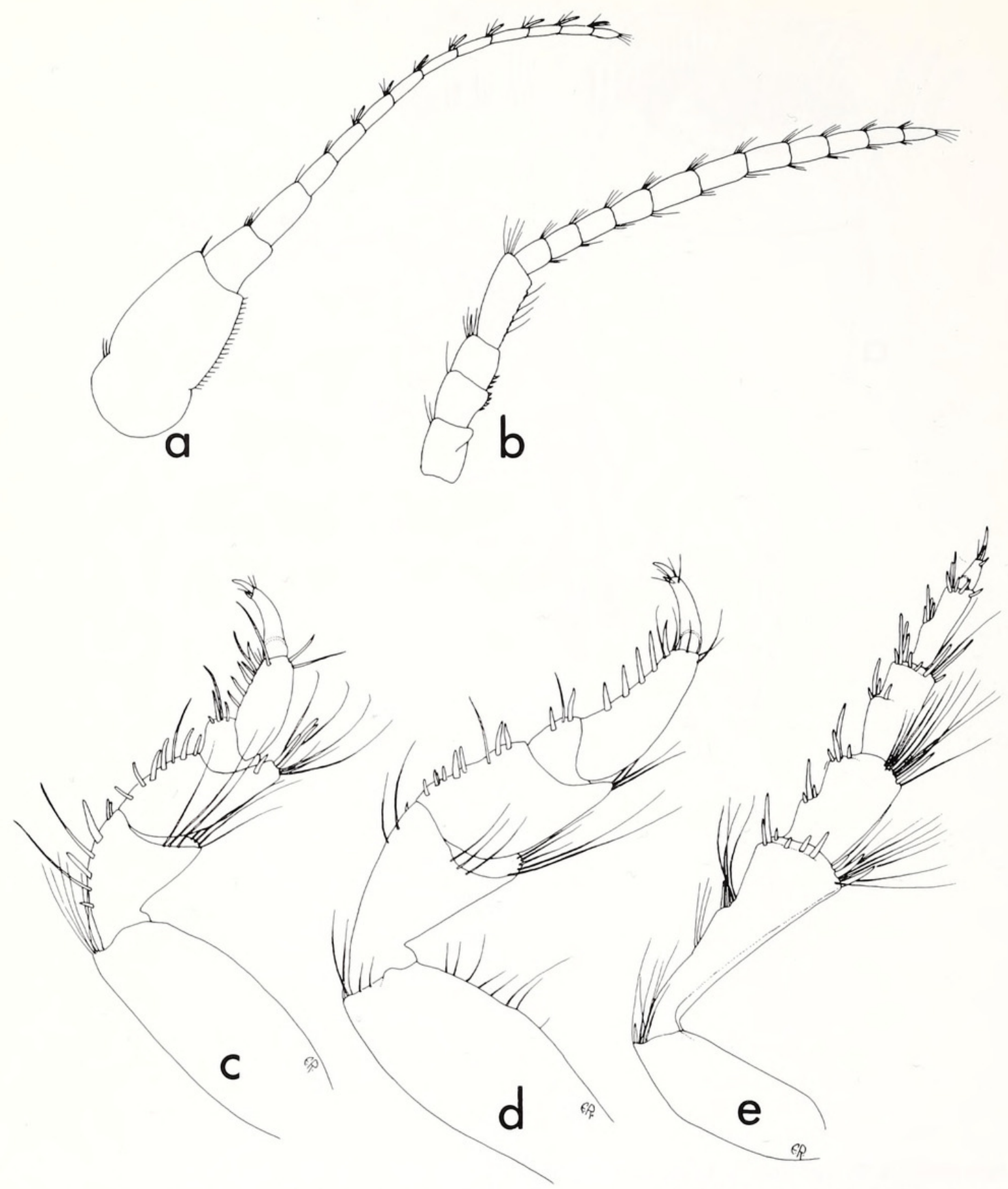

Figure 3. A, antennule. B, antenna. C, pereopod I. D, pereopod III. E, pereopod VII (from male paratype, LACM type No. 3014).

on inner margin; article 4 inner margin toothed and bearing simple setae; flagellum of 9-11 articles ( 8 in mancas). Although the antennules are always longer than the antennae, both tend to have the same number of flagellar articles on any given individual. Mandible with 4-cusped incisor, with 2 distolateral horns; inner cusp of left mandible markedly elongate; palp 2-articulate, distal article with 2 lateral setae and 2 long apical setae; lacinia and molar process well developed; molar process not extended much beyond apex of inner tooth of incisor. Maxillule inner lobe with 3 stout plumose setae and 1 short simple seta; outer lobe with about 10 stout setae and 1 slender seta. Maxilla inner lobe with 3 plumose setae and about 9 simple setae; bifurcate outer lobe with comb spines as figured. Maxilliped with 5-articulate palp, each article with simple setae; endite short, extending to middle of second palp article and bearing a single stout coupling hook.

Pereonite I longest, II-VII subequal in length, widest at IV-V; median row of stellate chromatophores on pereonites I-VII (chromatophores always present on pereonites VI-VII, usually present on IV-VII, occasionally present on I-III); chromatophores usually increasing in density posteriorly; 
coxal plates not visible in dorsal aspect. Pereopods all with acute dactyls and spines, never with blunt or stout truncate spines or dactyls. All pereopods with spines on inner margin of ischium through propodus, as figured. Pereopod VII ischium inner margin distinctly notched but with long setae only (no spines).

Pleonites subequal in width and length; all pleonites with lateral chromatophores, as figured. Submedian depressions on pleotelson distinct; chromatophores encircle depression, and occur centrally within it. Posterior border of pleotelson round, but with minute, barely discernable, truncate apical region, crenulate, and bearing long PMS. Uropodal endopod extended barely to pleotelson margin; exopod nearly twice length of endopod; both rami covered with minute setae; peduncle barely expanded on inner margin and with PMS, but with 3-5 stout spines on outer distal margin. Uropodal exopod with about 6 simple, thin, apical spines, 2 large medio-distal spines, and numerous minute spines or denticles along medial margin; PMS on inner margin. Uropodal endopod with 3 stout medial spines, and PMS as figured; lateral margin with a distinct pit. Pleopods 1-4 with coupling hooks; 1-3 with PMS on inner margin of peduncle; 3-5 with naked endopods; 1 with very narrow endopod; 5 with fully divided endopod. Appendix masculinum of male arises from proximal lamellar lobe of endopod, $1 / 3$ distance from base; stout and short, not reaching apex of endopod.

Taxonomic Remarks. Excirolana chamensis is a small species. Specimens of the type series range from 2.4 to 4.3 $\mathrm{mm}$ in total length; mancas range from 1.6 to $2.3 \mathrm{~mm}$ in length. Excirolana chamensis superficially resembles E. braziliensis, but can quickly be differentiated by its 2 -articulate mandibular palp (3-articulate in E. braziliensis), fully divided endopod on pleopod 5 (not fully divided in E. braziliensis), acute spines on all pereopods, small eyes, and distinct uropods on which the exopod bears a cluster of 6 fragile simple setae and 2 stout inner marginal setae. All specimens of $E$. chamensis we have examined have the distinct, large, stellate chromatophore pattern shown in Figure 1, which also quickly distinguishes this species from E. braziliensis, which has indistinct, punctate, or minute stellate chromatophores. We caution workers against relying on this character alone because it is possible that the chromatophores also occur in the punctate state in E. chamensis (although we have never observed such a case). J. Weinberg has preliminary (unpublished) data from the Chame Bay locality, indicating that the 2 cephalic chromatophore patterns shown in Figure 1 each occur in about $25 \%$ of the individuals, while intermediates comprise about $50 \%$ of the population. Other, more subtle characters that serve to differentiate $E$. chamensis from $E$. braziliensis include: (1) ischium of pereopod I with stout spines on inner margin (without spines in E. braziliensis); (2) ischium of pereopod III with a single spine on inner margin (with several spines in E. braziliensis); (3) ischium of pereopod VII without marginal spines (with several spine clusters or rows in E. braziliensis); (4) antenna peduncle article 3 subequal to 2 (longer than 2 in E. braziliensis); (5) maxilla inner lobe with PMS only on inner apical margin (all spines on inner lobe are plumose in E. braziliensis); (6) antennules always longer than antennae (in specimens of $E$. braziliensis less than $4 \mathrm{~mm}$ long, the antennules may be shorter than the antennae); (7) dorsal curvature (arching) of body much greater in E. chamensis; (8) marginal pit of endopod shallow in E. chamensis, deep in E. braziliensis. The function of the marginal pit on the uropodal endopod remains unknown, but seems to be diagnostic of almost all species in this genus.

Etymology. Excirolana chamensis is named after the type locality, Pt. Chame Bay, Pacific Panama.

Ecological Remarks. We have not performed tests to measure the adaptive value of the distinct dorsal chromatophore pattern of $E$. chamensis as possible camouflage from visual predators. Nonetheless, the high densities of small fishes and shorebirds in the surf zone at Chame Bay (pers. observ., J. Weinberg) suggest that camouflage may be important to the survival of these isopods. We have noticed that, unlike the sediments on most tropical Pacific beaches that are fairly homogeneous in color, Chame Bay beach sand is very heterogeneous. To the naked eye, Chame Bay sand is spotted black and white. The size of the black sediment particles is approximately the size of the stellate chromatophore region on the dorsum of $E$. chamensis. We hypothesize that the chromatophore pattern of this species is adaptive in reducing intensity of predation by visual feeders at Pt. Chame Bay. Such an adaptation might give $E$. chamensis the competitive edge needed to co-exist with other species of Excirolana that occur on mixed black/white sand beaches in the tropical east Pacific.

Considering that species of the genus Excirolana are usually the most abundant macroscopic invertebrates occurring on tropical American sand beaches, it is remarkable that this species, and others yet to be described, have not been discovered earlier. A number of studies have been published on Excirolana from tropical Pacific American shores (Bott, 1954; Brusca, 1980; Brusca and Iverson, 1985; Dexter, 1972, 1974, 1976, 1977, 1979; Glynn et al., 1975; Schuster, 1954; Schuster-Dieterichs, 1956; Weinberg, 1985). Most of these studies were allegedly concerned with $E$. braziliensis, probably the most common species in this region. Excirolana chamensis apparently has a highly restricted distribution. We have collected it only from the Panama City area, and the Perlas Islands (i.e., Pacific coast of Panama, between $79^{\circ}$ and $80^{\circ} \mathrm{W}$, and $8^{\circ}$ and $9^{\circ} \mathrm{N}$ ). We have examined thousands of specimens of Excirolana from over 100 locations in the eastern Pacific, ranging from Mexico to Chile, plus numerous samples from the Caribbean and Brazil, and in no other collections was this species found.

In addition to its restricted range, Excirolana chamensis is patchily distributed. Excirolana chamensis and E. braziliensis co-occur on at least four beaches in Panama. Based on samples collected in 1984, 1985, and 1986 by J. Weinberg, E. chamensis is very abundant at Pt. Chame Bay, outnumbering $E$. braziliensis by at least $9: 1$. This is the only location we have found where $E$. chamensis is dominant. It has also been collected from the following beaches: (1) San Telmo, in the Perlas Islands (by S. Garrity); (2) near the National Theater in Panama City (by J. Weinberg); and (3) under the 

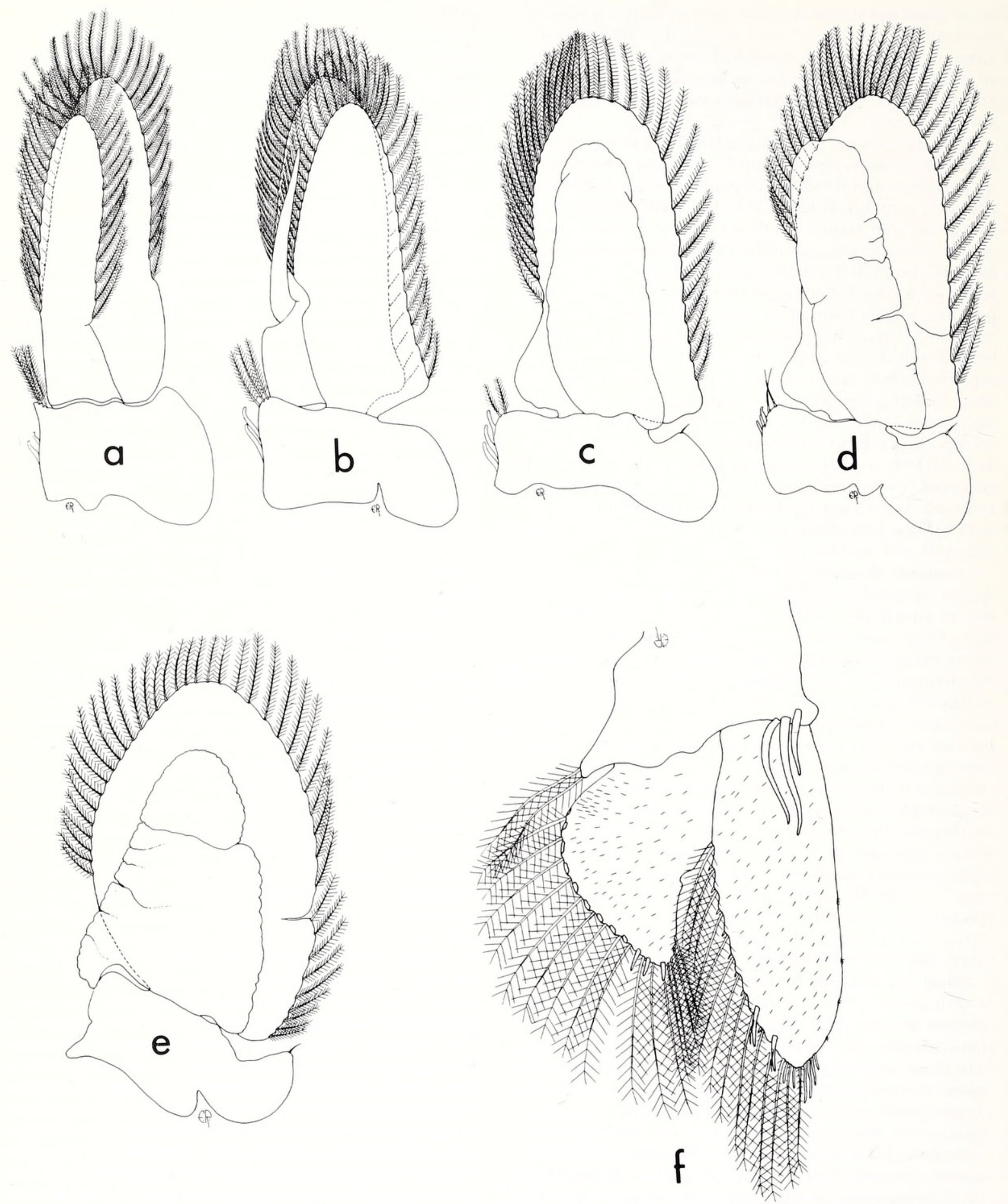

Figure 4. A, left pleopod 1. B, left pleopod 2. C, left pleopod 3. D, left pleopod 4. E, left pleopod 5. F, uropod (from male paratype, LACM type No. 3014). 
Bridge of the Americas, at the Pacific entrance to the Panama Canal (by J. Weinberg). In the San Telmo collection, the ratio of $E$. chamensis to E. braziliensis specimens is about 1:4; the collection from the Bridge of the Americas beach has a ratio of about 1:8. Excirolana chamensis was not present in collections from four other beaches in the Panama City area that contained populations of E. braziliensis. Beach sand from Pt. Chame Bay is barged into Panama City for various commercial purposes, and this activity could have introduced $E$. chamensis to beaches in this area (e.g., the "National Theater" site noted above) (Neal Smith, Smithsonian Tropical Research Institute, pers. comm.).

In a forthcoming paper by R. Brusca, several additional new species of Excirolana will be described from the tropical eastern Pacific and the status of E. braziliensis will be reassessed. At least one of the new species also occurs in the Panama City region. Recognition of these new species demands caution in interpretation of previous studies on $E x$ cirolana from this region.

\section{ACKNOWLEDGMENTS}

This research was supported by a National Science Foundation Grant to R.C. Brusca (BSR-8514093) and by postdoctoral fellowships to J.R. Weinberg from the Smithsonian Institution and Woods Hole Oceanographic Institution (W.H.O.I.). This is Contribution No. 6422 from W.H.O.I. Special thanks are extended to R. Wetzer for her assistance in the field and laboratory, and to our illustrator F. Runyan.

\section{LITERATURE CITED}

Bott, R. 1954. Ein neuer littoraler Isopod aus Peru. Senckenbergiana Biologica 35:107-108.

Brusca, R.C. 1980. Common Intertidal Invertebrates from the Gulf of California. 2nd Ed. Tucson, Arizona, University of Arizona Press, 513 pp.

Brusca, R.C., and E.W. Iverson. 1985. A guide to the marine isopod Crustacea of Pacific Costa Rica. Revista de Biologia Tropical 33, Supplement No. 1:1-77.

Dexter, D.M. 1972. Comparison of the community structures in a Pacific and Atlantic Panamanian beach. Bulletin of Marine Science 22:449-462.

- 1974. Sandy beach fauna of the Pacific and Atlantic coasts of Costa Rica and Colombia. Revista de Biologia Tropical 22:51-66.

- 1976. The sandy-beach fauna of Mexico. Southwest Naturalist 20:479-485.

- 1977. Natural history of the pan-American sand beach isopod Excirolana braziliensis (Crustacea: Malacostraca). Journal of Zoology, London 183:103-109.

_ 1979. Community structure and seasonal variation in intertidal Panamanian sandy beaches. Estuarine and Coastal Marine Science 9:543-558.

Glynn, P.W., D.M. Dexter, and T.E. Bowman. 1975. Excirolana braziliensis, a pan-American sand beach isopod: taxonomic status, zonation and distribution. Journal of Zoology, London 175:509-522.

Schuster, O. 1954. Zwei neue Crustaceen von der Pazifischen Kuste mittel-Amerikas (Amphipoda und Isopoda). Senckenbergiana Biologica 35:103-105.

Schuster-Dieterichs, O. 1956. Die Makrofauna am sandigen Brandungsstrand von El Salvador (mittelamerikanische Pazifikkuste). Senckenbergiana Biologica 37:156.

Weinberg, J.R. 1985. Evolutionary divergence of populations of a marine isopod in Panama: between ocean comparisons. American Zoologist 25:91A [abstract].

Submitted 13 February 1987; accepted 1 June 1987. 


\section{$2 \mathrm{BHL}$ Biodiversity Heritage Library}

Brusca, Richard C. and Weinberg, James R. 1987. "A new isopod crustacean from Pacific Panama, Excirolana chamensis new species (Isopoda: Flabellifera: Cirolanidae)." Contributions in science 392, 11-17. https://doi.org/10.5962/p.226826.

View This Item Online: https://www.biodiversitylibrary.org/item/216729

DOI: https://doi.org/10.5962/p.226826

Permalink: https://www.biodiversitylibrary.org/partpdf/226826

\section{Holding Institution}

Smithsonian Libraries

\section{Sponsored by}

Biodiversity Heritage Library

\section{Copyright \& Reuse}

Copyright Status: In Copyright. Digitized with the permission of the rights holder

Rights Holder: Natural History Museum of Los Angeles County

License: https://creativecommons.org/licenses/by-nc-sa/4.0/

Rights: https://www.biodiversitylibrary.org/permissions/

This document was created from content at the Biodiversity Heritage Library, the world's largest open access digital library for biodiversity literature and archives. Visit BHL at https://www.biodiversitylibrary.org. 